UDC: $378.147(07)+371: 811$

DOI: https://doi.org/10.24195/2414-4665-2017-8-8

Irina Kruhliak,

Doctor of Education, professor,

Director of Institute of Pedagogy, Staleva Volia, Poland,

Tetiana Mishenina,

Doctor of Pedagogic Sciences, associate professor, professor, Department of Ukrainian language Kryvyi Rih State Pedagogical University 54, Haharina Str., Kryvyi Rih, Ukraine ORCID iD 0000-0002-5992-4035

\title{
LINGUODIDACATIC TERMS CODIFICATION UNDER CONDITIONS OF INTERDISCIPLINARY INTEGRATION
}

The article is dedicated to the issue of codification of linguodidactic terms considering interdisciplinary integration. The development of linguodidactic competence of future philologists is determined by thOe formation of professional vocabulary that at the present stage of psychological and pedagogical thought is largely determined by integration disctinctness. It has been proved that the mediastructure of professional linguodidactic vocabulary is complicated by broadening basic terms functionality; interdisciplinary terms implication; rethinking of meaning associated with the terms codification. The integration principle defines further interpretation of special terms within such disciplines as: ethnosemiotics, linguoculturology, ethnolinguistics, psycholinguistics, linguogeography, ethno-pedagogy, culturology, paralinguistics.

Keywords: lexicography, interdisciplinary term, linguodidactic term, codification, integration.

\section{Introduction}

The development of Ukrainian linguodidactics contributes to the formation of the system of special terms, which are classified by means of interpretation using the paradigmatic and syntagmatic methods (revealing differential features, distinguishing paradigmatic groups; analysis of surveyed units compatibility (internal and external); methods of terms classification by lexicosemantic groups, areas; polysemy, synonymy, hypero-hyponymy (R. Yefimov [4], I. Kovalyk [5], I. Kochan [6], D. Lotte [7], N. Ostapenko [9], T. Panko [10]).

The process of training future professionals under conditions of integration is based on the achievements of schools of thought implemented in scientific disciplines curricula.

Domestic linguodidactics in the educational system defines integration-focused education. One can state the actualization of such values of the methods of teaching the Ukrainian language and literature which are manifested in interaction in every act of learning activities based on the specific philological profile, which is focused on communicative teaching and considers intercultural discourse. It makes it possible to conclude that communication as an educational discourse / intercultural communication is understood as a leading method of linguodidactics and at the same time is realized as an integral system of education. It is about an integrated approach to the system of teaching future philologists, which provides high-quality training in terms of "Pedagogy" major.
The paper aims to examine the peculiarities of linguodidactic terms codification on the basis of integration.

The following tasks should be solved:

- revealing the essence of linguodidatic terms codification on the integration basis;

- giving characteristics of structural and semantic features of linguodidactic definitions;

- defining linguodidactic potential of linguodidactic terms.

\section{Research methods}

The research is based on theoretical methods (analysis of psychological, educational and linguistic literature), and empirical ones (linguistic - component and etymological analysis).

The technique (I. Kovalyk [5], I. Kochyn [6], D. Lotte [7], T. Panko [10]) which helps to define the terminological field, is based on the application of criterial indicators, and determines the following parameters:

1) terminological field has to cover the core and circumference where (in terms of our research) linguodidactic terms have to create a specific combination which performs communication-thematic or communicationsituational tasks;

2) elements of the system directly or indirectly interact with one another and the system in general;

3) boundaries between terms can be less or more clear;

4) the term systems can overlap, providing their intercrossing (integration in terms of psycho-pedagogical and linguistic terms systems); 
5) a term system can be used both by a certain branch or some branches simultaneously, which means that it can perform a function of interdisciplinary terminological fund (linguodidactic terms act like leading concepts both in the methodological domain and in terms of the development of terms' normalization).

The concept of a norm in the system of special terms should be based on the normative accuracy, clearness, systematicity of terms, as well as lexical grammatical and word-building normativity.

It is appropriate to describe the main features of a terminological norm which we use for codification of the system of linguodidactic field at the level of lexicographic articles:

1. Correlation of a term and a concept. The main criterion of referring a lexical unit to a class of terms is its belonging to a certain system of special concepts, namely to a relevant terminological field.

2. Monosemy of a term within a certain terminological system. Considering the fact polysemy complicates the mutual understanding of specialists of a certain sphere, interdisciplinary functioning requires specification in relevant dictionaries. In order to prevent polysemy one should avoid improper borrowing of the terms from other languages.

3. Term's accuracy is associated with its inner form. The meaning, morphology and syntax relations define its accuracy.

4. Term's neutrality excludes its expressivity and emotional coloring.

5. Term's conciseness puts forward requirements to its structure: in terms of human psyche there should be not more than five components.

6. Limitedness of synonyms and homonyms. System interrelations provide the synonymization at the level of alternatives, while homonymization requires additional comments

The structural and semantic analysis of linguodidactic terms implies the use of linguistic analysis method which involves a set of research tools. In order to reveal structural peculiarities of lexemes we use two groups of techniques: linguistic and denotation approaches which are interpreted in relevant research tools - logical, culturological, psycholinguistic, and linguistic (V. Batsevych [1], H. Matsiuk [8], V. Yartseva [12]).

We use a denotative approach to the structure of linguodidactic definition in order to reveal the extralinguistic aspects of a lexeme which includes a historic reference about the issue studied, as well as defining synchronic and diachronic characteristics.

\section{Research Results and Discussion}

The competence of modern linguodidactics in term of integration processes is the revealing of factors of cultural interaction; providing communicational orientation of learning situations taking into account the reflective positions of the dialogue participants; the development of tiered characteristics with further examination of linguis- tic, communicative, intercultural, and culturological competencies.

The performed quantitative analysis gives a chance to conclude about a systemic display of linguodidactic terms in specialized dictionaries $[3 ; 9]$. The systematization of linguodidactic terms actualizes the issue of codification (bringing together, normalization, standardization, standardization of lexemes). In terms of the analyzed concept, we define absolute (invariant) and relative (variant) codifications. According to our observations relative codification is primarily associated with the parallel use of foreign and Ukrainian equivalents (communication спілкування, ethnography - народознавство, innovation - нововведення, creativity - творчість; etnomentality етносвідомість, competence - обізнаність). According to the carried out component analysis, the parallel use of linguodidactic terms, the national equivalent mostly does not implement all the meanings of the foreign equivalent.

Considering the features of codification of linguodidactic terms (such as prospectivity (phenomena are codified considering the predictable development of a literary language by eliminating variants); synchronous dynamics of a literary norm (assists in the development of a literary norm) $[8$, c. 34-35; 6]) we can note their consistency at the level of field structure, where the relevant feature of term correlation with the signified concept is the definition within the core / circumference of a thematic field; at the same time a linguodidactic term has a denotation of relevant scientific concept in its structure-semantic system.

As the systematicity of Ukrainian terms reveals itself in a way of expression and content, the concept is treated as a class of specific phenomena (in our case - linguodidactic); the content as a set of essential features of the analyzed phenomena. The main meaning of a term consistently recreates the meaning of a term. At the same time, it is necessary to pay attention to the structural and semantic feature of a term, which means that semantic specifier of a term in significatum recreates additional / clarifying data regarding a generic concept. A good example is the range of connotative specifiers: the parameter (one that measures) from a position of intercultural communication: the parameter of communicative behavior (set of congeneric communicative features which characterize communicative behavior of an ethnicity [1, $\mathrm{p}$. 130]); the parameter of linguocultural individualism / collectivism (a measure of expression in communication of linguoculture members).

Differential linear compatibility of linguodidactic terms helps to create terminological models at the level of syntagmatic (the concept of valency) field. Valency from a position of formal laws of word elements compatibility [4] can be presented by the composites of elements, forming an associative paradigm. A syntagmatic field that is represented by the Ukrainian terms with the element (suffix) "-фон” can serve as an example: фонова лексика / background vocabulary (lexemes that contain information of national culture), фонові знання / background knowledge, фон культурний слова / cultural background of 
a word (characteristics of nominative units, which represent the phenomena of social life and historical events), etc.

Terms combination "background knowledge" interpreted from a position of linguistics as scientific systematic knowledge of information and cultural nature, is not always directly linked to literary text / art product, but without it the understanding is impossible; it is the knowledge which cannot be revealed from a certain literary text, but which is hidden for the bearer of linguoculture / reader (sometimes for a writer).

In terms of the communicative function of a language, background knowledge similar to intercultural communication is considered as multicultural knowledge of realias by a speaker and a listener, which forms the basis of verbal communication.

As background knowledge represents certain information and certain concepts of linguoculture, linguistic analysis involves taking into account:

a) human knowledge, covering common to all mankind concepts;

b) regional information which reproduces autochthonity of knowledge about the realias associated with regional living conditions;

c) knowledge, peculiar to all members of certain ethnic and linguistic communities and associated with national traditions, culture - the so-called regional studies.

From the position of nonlinear compatibility of linguodidactic terms, linguistic patterns correlate with extralinguistic direction, which provides adequate combination of elements of terms and occurs considering their semantic coherence, which reflects the connections and relations of objects and phenomena of psychological and educational and linguistic fields.

For instance, the concept "linguistic situation" (Ukr. “мовна ситуація"), which in terms of intercultural integration is conformable as a sociolinguistic concept because it means a set of languages in their functional interactions; affects the course of intercultural communication, determines the effectiveness and thematic development of mono- / polylinguocultural situation. It involves schemes, in which the progress of communication is summarized; defines national models of speech behavior in accordance with the cultural stereotype of specific communication; expression of mentality; tiered paradigm of mentality of a particular ethnic group.

It should be noted that the ascertainment of the features of structural and semantic changes of terms primarily involves:

a) observation of changes in the semantic structure, content and nature of the definitional meanings in terms of lexical-semantic system of a language and stylistic functioning in it;

b) realignment of meanings in the semantic structure of linguodidactic terms, which is determined by the development of a new meaning, that is the extension of semantic nuances;

c) adjustment to the lexical-semantic language system through interaction with the words with similar mean- ing. Studying the semantics of terms according to the described procedures enables their complete and accurate lexicographic interpretation.

There is complication of semantic structure of the examined combination of terms, expanding of semantic nuances of components "linguistic" / (Ukr. “мовленнєвий”) (monolingual, bilingual, polylingual), "situation" / (Ukr. "ситуаціiя”) (dialogization, communication, discourse, interculturation).

Linguodidactic interpretation of the examined combinations of terms allows to implement such ones as a "communicative situation" / (Ukr. "ситуаичiя спілкування") (discursive, spatio-temporal circumstances of communication); "monolinguistic situation" / (Ukr. “ситуація монолінгвістична") / "polylinguistic situation" / (Ukr. "полілінгвістична") (type of linguocultural situation in terms of national / multicultural communities); "precedent situation" / (Ukr. “ситуачія прецедентна") (the situation related to the actualization of connotative nuance which form the cognitive basis of culture representatives) into the conceptual apparatus of the interdisciplinary course.

Dynamic processes, which take place in the semantic structure of a word, are marked with such features as the specialization of meaning as a result of the narrowing of the scope and enrichment of content; transition of name based on spatial, time or causal relationships [11]. According to our observations, linguodidactic terminology represents mainly specialization of the meaning, whose integrational determination makes it possible to talk about both the equality, identity (match of two objects of concepts), namely synonymy, and submission, inclusion that generates two oppositely directed semantic processes - expansion or constriction.

Integrational determination of semantic shifts in the content of linguodidactic terms represents the relationship of overlapping as a transfer.

Linguodidactic principles of teaching lexicology and phraseology provide the mastering of lexicon as a system. Integrational principle being the basis of the formation of modern linguodidactic lexicon, allows to classify series of generic concept "Lexicon" / "лексика" to the codified linguodidactic terms. Its linguistic interpretation is as follows: "vocabulary structure of a language which is described in lexicographical works" [2;6]. Integration determination of semantic changes of the examined terms makes it possible to distinguish the following combinations of terms within the field structure:

- equivalent lexicon covers the lexemes whose meanings have common semantic components with the lexemes of a native language of another intercultural communication participant. To the equivalent lexicon within linguodidactics and taking into account the characteristics of the term systematicity and functionality - we allot the lexemes which are translated arbitrarily, according to the lexicographical data and reproduced in the monolingual dictionaries of languages.

From the position of forming linguocultural and linguistic competence of linguistic identity, it is about the iden- 
tification of the equivalent lexemes, which are presented in the linguistic analysis of the text. Thematic fields in terms of linguistic image of the world can serve as examples: astronomic - sun, wind, water, earth, sky, moon. The equivalent lexicon does not reflect national and cultural specificity; translation can be used for their interpretation.

Speaking of equivalent lexicon, we should distinguish cross-language lexicon, and borrowed lexicon (except for exoticisms).

There are the following ways of assimilation of the borrowed lexicon by a language-recipient according to the degree of adaptation of foreign words:

a) assimilation - words that have been grammatically and phonetically adapted to the borrowing language;

b) borrowings - words in which the process of adjustment has not been completed.

As noted before, many researchers believe that the word is borrowed from one linguistic system to another one with a single meaning, while they are not the same in relation to the word-etymon in the source language, depending on which we can single out two types of communication:

1) a monosemantic word in the language may correspond to a monosemantic word-etymon;

2) a monosemantic word in the Ukrainian language can correlate with one of the meanings of the polysemantic word-etymon.

- non-equivalent lexicon covers the lexemes whose meanings have no common semantic components with the words of the native language of another participant of intercultural communication. As non-equivalent lexicon is not comparable with the vocabulary of another language and represents a national specific linguistic image; from a position of linguodidactics we can talk about formed correlation of linguocultural competence and active nonequivalent vocabulary.

Exoticisms are the words with particularly expressive load of a foreign language in which adaptation has just started or has not yet begun - they reproduce autochthonity of linguoculture, and belong to non-equivalent vocabulary.

Non-equivalent vocabulary covers background lexicon, which needs cultural and linguistic commenting in the process of lexical and stylistic analysis. Accordingly, we correlate non-equivalent lexicon with contrastive lexicon, which represents the so-called linguocultureme - a complex concept that is used in cases of analysis of interlevel linguocultural features of units and categories of certain ideoethnic language.

Dictionary entry of a linguocultureme includes such meanings of implementation:

-lingvocultureme-realia (national artifact);

-significative linguocultureme (denotation that is common to comparable linguoculturemes);

-connotative lingvocultureme (includes cultural information in the connotation of the linguistic sign);

- tropeistic lingvocultureme (having culturological seme in denotation of the content, as a result of the trans- fer of meanings and meanings shift that realize additional connotative culturological seme);

- symbolic lingvocultureme (linguistic signs that include cultural content and express the features of ideology of national linguoculture and are perceived in the society as symbols);

- symbolic lingvoculturemes of socio-national behavior (verbal etiquette).

Mediastructure of a professional linguodidactics vocabulary is also complicated through the implementation of terms that are considered to be interdisciplinary to the categorical and conceptual apparatus. In particular, the concept of culture - (lat. Cultura - processing and as a result - the formation, development) is understood in a broad sense as a set of material and spiritual values created by human community which characterize a certain level of a society; culture is the level of spiritual life; interpretive model of the human world, that is socialized in certain circumstances.

Linguodidactic interpretation of the examined generic concept allows to include the following term combinations into the structure of the dictionary at the level of codification: culture of speech - a) possession of rules of oral and written forms of a literary language in various spheres of public communication for the purpose and content of communication at the level of normativity, correctness; b) from a position of interculturation - conscious, purposeful and critical use of the means of a language, with which the cross-cultural communication is realized; communicative culture (communicative behavior of an ethnicity as a part of its national culture, national spiritual culture fragment which is responsible for the communicative behavior of an ethnicity); ethno-spiritual culture (a set of values implemented in the process of learning and producing by a person, national linguocultural community of cultural potential of the society, its spiritual sphere).

\section{Conclusion}

Codification of modern linguodidactic terms considers the parameters of word definition (correlation of a term and a concept, monosemy, accuracy, neutrality, etc.), as well as integration of related fields.

The mediastructure of a dictionary of linguodidactic terms is complicated in accordance with the principle of integration, that is manifested in:

1) expanding the functionality of basic terms;

2) implementation of interdisciplinary terms;

3 ) reconsideration of the concepts related to the codification of terms that form the previous two groups.

Modern linguodidactic field of terms is defined by the interdisciplinary semantics. The integration principle determines further interpretation of special terms within related disciplines (ethnosemiotics, linguistics, ethnolinguistics, psycholinguistics, linguistic geography, ethnopedagogics, cultural science, linguohistory of a region, paralinguistics), as well as corresponding reconsideration of categorical linguodidactic apparatus at the level of scientific foundations of competences formation. 
The changes in the semantic structure of linguodidactic terms determine the relevant interpretation of methods of language learning (it is primarily referred to the dictionary entry concerning the determination of the definitions of its characteristics of linguodidactic principles of teaching lexicology and phraseology; linguistic,

\section{REFERENCES}

1. Batsevych, F.S. (2007). Slovnyk terminiv mizhkulturnoyi komunikatsiyi [Dictionary of intercultural communication terms]. Kyiv: Dovira [in Ukrainian].

2. Vereshhagyn, E.M., Kostomarov, V.G. (1983). Yazyk $i$ kultura: Lingvostranovedenie $v$ prepodavanii russkogo yazyka kak inostrannogo [Language and culture: linguocultural studies in teaching Russian as a foreign language]. $3^{\text {rd }}$ ed. Moscow: Rus. yaz. [in Russian].

3. Kremen, V.H. (Ed.). (2008). Entsyklopediya osvity [Encyclopedia of education]. Kyiv: Yurinkom Inter [in Ukrainian].

4. Efymov, R. V. (1977). Vnutrennyaya valentnost slova: teoryya y praktyka: uchebnoe posobye [Internal valency of the word: textbook]. Kharkov: Yzd-vo Khark. hos. u-ta ym. Horkoho [in Russian].

5. Kovalyk, I. I. (1969). Logiko-lingvistychna problematyka tekhnichnoi terminolohii u slovianskykh movakh [Lofical and linguistic problematics of technical terminology in Slavic languages]. Visnyk Lvivskogo derzhavnogo universytetu im. Ivana Franka: Seriya filologichna - Bulletin of Lviv state university named after Ivan Franko, 6, 19-24. Lviv [in Ukrainian].

6. Kochan, I.M. (2006). Systemnist, dynamika, kodyfikatsiia sliv z mizhnarodnymy korenevymy komponentamy $\mathrm{v}$ suchasnii ukrainskii movi [Systematicity, dicamics, codification of words with international core components in the modern Ukrainian language]. Doctor's thesis. Lviv [in Ukrainian].

7. Lotte, D.S. (1982). Voprosy zaimstvovaniya $i$ uporyadocheniya inoyazychnykh terminov $i$ terminoele-

\section{ЛІТЕРАТУРА}

1.Бацевич Ф.С. Словник термінів міжкультурної комунікації / Ф.С. Бацевич. - К. : Довіра, 2007. - 205 c.

2.Верещагин Е.М., Костомаров В.Г. Язык и культура: Лингвострановедение в преподавании русского языка как иностранного / Е.М. Верещагин, В.Г. Костомаров. - 3-е изд. - М.: Рус. яз., 1983. - 269 с. - с. 98 , c. 212

3.Енциклопедія освіти : [гол. ред. В.Г.Кремень]. - К. : Юрінком Інтер, 2008. - 1040 с.

4.Ефимов Р. В. Внутренняя валентность слова: теория и практика : учебное пособие / Р.В. Ефимов, В.И. Каравашкин. - Харьков: Изд-во Харьк. гос. у-та им. Горького, 1977. - 87 с.

5.Ковалик I. I. Логіко-лінгвістична проблематика технічної термінології у слов'янських мовах / I.I. Ковалик // Вісник Львівського державного університету extralinguistic, psycholinguistic factors of lexicon and phraseology learning, etc.).

System interrelations of linguodidactic terms are manifested at the level of synonymziation and syntagmatic determinations. According, the core and circumference of the linguodidactic field of term is filled by means of additional characteristics of the object studied.

mentov [Issues of borrowing and structuring of foreign terms and their elements]. Moscow: Nauka [in Russian].

8. Matsyuk, H. P. (2001). Preskryptyvne movoznavstvo $v$ Halychyni [Perspective linguistic studies in Halychchyna]. Lviv: Vyd-vo Lviv.nats. u-tu im. Ivana Franka [in Ukrainian].

9. Ostapenko, N.M. (2010). Teoretychni i metodychni zasady formuvannya linhvodydaktychnoyi kompetentnosti u maybutnikh uchyteliv ukrayins'koyi movy i literatury [Theoretical and methodical bases of forming linguodidactic competence in future teachers of Ukrainian language and literature]. Doctor's thesis. Kyiv [in Ukrainian].

10. Panko, T. I. (1991). Metodologichni zasady vyvchennya i rozvytku natsionalnoi terminolohii [Methodological bases of studying and developing national terminology]. Teoriya ta prahmatyka terminolohichnoi leksyky: tezy dop. resp. nauk.-metod. konf. -Theory and pragmatic of terminological lexicon: proceedings of the scientific conference, (pp. 73-74). Kyiv: NMK VO [in Ukrainian].

11. Rusanivskyy, V. M., Taranenko, O. O., Zyablyuk, M. P. (Ed.). (2004). Ukrayinska mova: entsyklopediya [The Ukrainian language: encyclopedia]. $2^{\text {nd }} \mathrm{ed}$. rev. Kyiv: Vyd-vo «Ukrayinska entsyklopediya» im. M. Bazhana [in Ukrainian].

12. Yartseva, V.M. (1981). Kontrastivnaya gramatika [Comparative grammar]. Moscow: Prosveshchenye [in Ukrainian].

ім. Івана Франка: Серія філологічна. -Львів, 1969. Вип. 6. - С. 19-24., С. 22.

6. Кочан I.M. Системність, динаміка, кодифікація слів 3 міжнародними кореневими компонентами в сучасній українській мові : дис. ... д-ра філол. наук ; спец. 10.00.02 - українська мова / Ірина Миколаївна Кочан. - Львів, $2006 .-564$ с., С. 105.

7. Лотте Д.С. Вопросы заимствования и упорядочения иноязычных терминов и терминоэлементов / Д.С. Лотте. - М.: Наука, 1982. - 149 с., С. 21.

8. Мацюк Г. П. Прескриптивне мовознавство в Галичині (перша половина X1X ст.) / Г.П. Мацюк. Львів: Вид-во Львів.нац. у-ту ім. Івана Франка, 2001. $372 \mathrm{c}$.

9. Остапенко Н.М. Теоретичні і методичні засади формування лінгводидактичної компетентності у майбутніх учителів української мови і літератури : 
дис. ... доктора пед. наук ; 13.00 .02 / Наталія Миколаївна Остапенко. - К., 2010. - 471 с.

10. Панько Т. I. Методологічні засади вивчення й розвитку національної термінології / Т.І. Панько // Теорія та прагматика термінологічної лексики: тези доп. респ. наук.-метод. конф. - К.: НМК ВО, 1991. C. $73-74$, C. 73 .
11. Українська мова : [енциклопедія] / ред. кол. : В. М. Русанівський, О. О. Тараненко, М. П. Зяблюк та ін. - [2-ге вид., випр. і доп.]. - К. : Вид-во «Українська енциклопедія» ім. М. Бажана, 2004. - 864 с. : іл.

12. Ярцева В.М. Контрастивная граматика / В.М. Ярцева. - Москва: Просвещение, 1981. - 112 с.

Ірина Кругляк, доктор педагогічних наук, професор, директор Інституту педагогіки, Стальова-Воля, Польща, Тетяна Михайлівна Мішеніна, доктор педагогічних наук, професор, дочент кафедри украӥнської філології, Криворізький державний педагогічний університет, вул. Гагаріна, 54, м. Кривий Ріг, Украӥна

\section{КОДИФІКАЦІЯ ЛІНГВОДИДАКТИЧНИХ ТЕРМІНІВ В УМОВАХ МІЖГАЛУЗЕВОЇ ІНТЕГРАЦІЇ ЯК ЛЕКСИКОГРАФІЧНА ПРОБЛЕМА}

Статтю присвячено питанню кодифікації лінгводидактичних термінів з урахуванням міжгалузевої інтеграції. Вироблення лінгводидактичної компетенції майбутніх філологів детерміноване сформованістю фахового словника, який на сучасному етапі розвитку психолого-педагогічної думки значною мірою визначається інтеграційною означеністю. Доведено, що медіаструктура фахового словника 3 лінгводидактики ускладнюється шляхом розширення функціональності базових термінів; уведення міжгалузевих термінів; переосмислення понять, пов'язаних із кодифікацією термінів, які складають попередні дві групи. Структурно-семантичні особливості лінгводидактичних термінів зумовлені динамікою семантичної структури, обсягом й характером дефініційних значень у змісті лексико-семантичної системи мови й стильовим функціонуванням у ній. Процес перегрупування значень у семантичній структурі лінгводидактичних термінів зумовлений розвитком нового значення, яке пов'язане 3 розширенням значеннєвих відтінків. Адаптація фахових термінів психологопедагогічної галузі до лексико-семантичної системи мови досягається шляхом взаємодії з близькими за значенням словами. Інтеграційну детермінацію семантичних зрушень у змісті лінгводидактичних термінів репрезентують відношення перехрещування як перенесення. Досліджено, що ускладнення медіаструктури лінгводидактичного словника досягається шляхом уведення до категорійно-поняттєвого апарату термінів, які кваліфікуються як міжгалузеві. Новітню інтерпретацію знаходять такі міжгалузеві поняття, як культура, мовна особистість, мовна ситуаиія. Зважаючи на те, що інтеграційний принцип визначає подальшу інтерпретацію спеціальних термінів в межах таких суміжних галузей (етносеміотика, лінгвокультурологія, етнолінгвістика, психолінгвістика, лінгвогеографія, етнопедагогіка, культурологія, лінгвокраєзнавство, паралінгвістика), констатуємо відповідне переосмислення категорійного апарату лінгводидактики на рівні наукових засад вироблення компетенцій. Зміна в семантичній структурі лінгводидактичних термінів детермінує відповідну інтерпретацію методики навчання мови (ідеться насамперед про словникові статті, які стосуються визначення дефініцій них характеристик лінговдидактичних засад навчання лексикології і фразеології; лінгвістичного, екстралінгвістичного і психолінгвістичного чинників вивчення лексики і фразеології).

Ключові слова: лексикографія, міжгалузевий термін, лінгводидактичний термін, кодифікація, інтеграція.

Submitted on June, 12, 2017 